\title{
Analisis Struktur Ekonomi dan Ketimpangan \\ Antar Sektor di Kabupaten Tebo Periode 2001-2010
}

\author{
Oleh: \\ *)Ahmad Soleh \\ **)Dosen Tetap STIE Muhaammadiyah Jambi
}

\begin{abstract}
Abstrak
Penelitian ini bertujuan untuk mengetahui dan menganalisis: (1) Struktur dan pola Pertumbuhan Sektor Ekonomi di Kabupaten Tebo selama Periode 2001-2010 (2) Sektor mana yang menjadi Sektor Unggulan di Kabupaten Tebo (3) Tingkat Ketimpangan antar Sektor di Kabupaten Tebo.

Hasil Penelitian menunjukkkan bahwa Struktur Pertumbuhan Ekonomi di Kabupaten Tebo dalam Pembentukan PDRB selama Tahun 2001-2010 masih didominasi oleh sektor Primer (Pertanian,Pertambangan), dimana rata-rata kontribusi sektor Primer sebesar 54,87 persen, sedangkan untuk Pola Pertumbuhan sektor Ekonomi berdasarkan analisis Tipologi Klassen terlihat bahwa sektor Ekonomi tidak ada yang berada pada kuadran II yaitu sektor maju dan tumbuh cepat tetapi berada pada kuadran I, III dan kuadran IV hal ini disebabkan karena Kabupaten Tebo merupakan Kabupaten pemekaran dimana sektor-sektor perekonomian masih memungkinkan untuk di kembangkan, dan kekayaan berupa sumber daya alam belum maksimal dimanfaatkan.

Sedangkan berdasarkan analisa menggunakan Indek Balance Growth nilai keseimbangan antar sektor ekonomi di Kabupaten Tebo yaitu sebesar 1,54, hal ini meggambarkan bahwa pertumbuhan ekonomi antar sektor tidak seimbang atau terjadi ketimpangan antar sektor di Kabupaten Tebo.
\end{abstract}

Kata kunci : Pertumbuhan Ekonomi , Kontribusi sektoral dan Ketimpangan Antar Sektor Ekonomi.

\section{Latar Belakang}

Pemerintah Daerah di Indonesia telah mengalami perubahan seiring dengan diberlakukannya otonomi daerah, dengan mendekatkan pembuatan keputusan ke daerah, Pemerintah Pusat telah memberikan kewenangan kepada Pemerintah Daerah untuk mengatur urusan pembangunan ekonominya sendiri, Seperti yang tertuang dalam UUNo.33 Tahun 2004 tentang Perimbangan Keuangan antara Pemerintah Pusat dan Daerah.

Pertumbuhan ekonomi berarti perkembangan kegiatan dalam perekonomian yang menyebabkan barang dan jasa yang diproduksi bertambah dan kemakmuran masyarakat meningkat, sedangkan laju pertumbuhan ekonomi diartikan sebagai kenaikan dalam PDRB 
tanpa memandang apakah kenaikan itu lebih besar atau lebih kecil dari tingkat pertumbuhan penduduk dan apakah ada perubahan atau tidak dalam struktur ekonomi. PDRB dikategorikan dalam berbagai sektor ekonomi dan perbedaan tingkat pembangunan akan membawa dampak perbedaan tingkat kesejahteraan antar daerah yang pada akhirnya menyebabkan ketimpangan regional antar daerah semakin besar. Pertumbuhan ekonomi adalah salah satu tolak ukur yang dapat dipakai untuk meningkatkan adanya pembangunan suatu daerah dari berbagai macam sektor ekonomi yang secara tidak langsung menggambarkan tingkat pertumbuhan ekonomi.

Sejak pemekaran wilayah dari Kabupaten Bungo Tebo, perekonomian Kabupaten Tebo selama periode 2001 - 2010 menunjukkan trend yang positif setiap tahunnya. Terlihat dari peningkatan nilai Produk Domestik Regional Bruto (PDRB) sebagai salah satu indikator ekonomi daerah sebagaimana terlihat pada tebel berikut:

Tabel 1. Laju Pertumbuhan PDRB Kabupaten Tebo dan Provinsi Jambi Periode Tahun 2005 - 2009 (dalam jutaan rupiah)

\begin{tabular}{|c|c|c|c|c|c|}
\hline NO & TAHUN & $\begin{array}{c}\text { PDRB } \\
\text { Kab. Tebo }\end{array}$ & $\begin{array}{c}\text { Pertumbuhan } \\
(\%)\end{array}$ & $\begin{array}{c}\text { Provinsi } \\
\text { Jambi }\end{array}$ & $\begin{array}{c}\text { Pertumbuhan } \\
(\%)\end{array}$ \\
\hline 1 & 2005 & 663.470 & - & 12.517 .179 & - \\
\hline 2 & 2006 & 727.525 & 9.65 & 13.248 .345 & 5,84 \\
\hline 3 & 2007 & 767.278 & 5.46 & 14.146 .387 & 6,78 \\
\hline 5 & 2008 & 813.852 & 6.07 & 15.164 .152 & 7,19 \\
\hline 5 & 2009 & 855.265 & 5.09 & 16.141 .847 & 6,58 \\
\hline \multicolumn{7}{|c|}{ RATA-RATA } & $\mathbf{3 , 2 2}$ & & $\mathbf{4 , 9 5}$ \\
\hline
\end{tabular}

Sumber : BPS Kabupaten Tebo dan BPS Provinsi Jambi beberapa penerbitan

Secara makro pertumbuhan atau kenaikan PDRB dari tahun ke tahun merupakan salah satu indikator keberhasilan pembangunan daerah, dimana dalam hal ini PDRB dikategorikan ke dalam berbagai sektor ekonomi yaitu : (1) Sektor Pertanian (2) Sektor Pertambangan (3) Sektor Industri Pengelolahan (4) Sektor Listrik, Gas dan Air Bersih (5) Sektor Bangunan (6) Sektor Perdagangan, Hotel dan Restoran (7) Sektor Anggkutan dan Komunikasi (8) Sektor Keuangan, Persewaan dan Jasa Perusahaan (9) Sektor Jasa-jasa.

Pertumbuhan PDRB tidak lepas dari peran setiap sektor ekonomi tersebut diatas, besar kecilnya kontribusi pendapatan setiap sektor ekonomi merupakan hasil perencanaan serta pembangunan sektoral yang dilaksanakan didaerah. Keberhasilan pembangunan suatu daerah sangat ditentukan keberhasilan dalam melaksanakan strategi perencanaan pembangunan daerah dengan mengoptimalkan semua potensi. Secara konseptual upaya untuk menganalisis perekonomian suatu daerah memiliki arti yang cukup penting untuk dilakukan. Hal ini selain berguna dalam memberikan informasi mengenai kondisi ekonomi suatu daerah juga dapat 
dijadikan bahan pertimbangan penting dalam merumuskan kebijaksanaan perekonomian didaerah yang bersangkuan.

Kabupaten Tebo merupakan salah satu dari 11(sebelas) Kabupaten/Kota yang memiliki letak geografis yang sangat strategis karena berada di jalur lintas Sumatera, selain itu beberapa potensi penting dan strategis mempunyai peluang pasar lokal dan ekspor.

Pertumbuhan ekonomi menghasilkan penggeseran struktur ekonomi hanya merupakan salah satu segi dari hasil pembangunan secara kuantitatif, sedangkan kualitas dari pembangunan itu sendiri mempunyai arti sejauh mana manfaat dari pertumbuhan ekonomi tersebut dapat dinikmat secara merata oleh masyarakat. Dalam lingkup daerah suatu negara, suatu sektor dikatakan mempunyai daya saing apabila sektor tersebut tidak hanya laku di jual dipasar lokal di daerahnya sendiri, melainkan juga dapat bersaing diluar daerahnya. Dari sisi penawaran agregat, suatu subsektor dari suatu daerah dapat dikatakan mempunyai daya saing apabila sektor tersebut tidak hanya mampu memenuhi kebutuhan sendiri, melainkan juga dapat memenuhi kebutuhan daerah lain. Sektor yang mempunyai karakteristik demikian dinamakan sebagai sektor basis. Sedangkan sektor unggulan merupakan sektor ekonomi yang melayani baik pasar domestik maupun luar daerah itu sendiri, secara tidak langsung daerah mempunyai kemampuan untuk mengekspor barang dan jasa yang dihasilkan oleh sektor tersebut ke daerah lain. Sektor non unggulan yaitu sektor yang hanya mampu melayani pasar di daerahnya sendiri (Tan : 2010)

Struktur perekonomian suatu daerah merupakan gambaran langsung dari komponen seluruh kegiatan produksi barang dan jasa yang dilakukan di wilayah tersebut. Adanya perubahan struktur produksi akan menyebabkan pergeseran struktur ekonomi di wilayah yang bersangkutan. Indikator yang sering dipakai untuk mengamati struktur perekonomian suatu daerah adalah distribusi persentase sektoral yang juga dapat digunakan untuk mengamati keunggulan daerah. Proses perubahan struktur perekonomian ditandai dengan: (1) menurunnya pangsa sektor primer (pertanian), (2) meningkatnya pangsa sektor sekunder (industri), dan (3) pangsa sektor tersier (jasa) juga memberikan kontribusi yang meningkat sejalan dengan pertumbuhan ekonomi (Todaro, 1999).

Salah satu upaya yang dapat dilakukan untuk mempertahankan kelanjutan ekonomi wilayah adalah memanfaatkan secara optimal potensi ekonomi wilayah, pendapatan sumber daya alam suatu wilayah untuk dijadikan subsektor basis yang memegang peranan penting sebagai pengerak utama dalam meningkatkan perekonomian daerah. Dalam penentuan subsektor basis atau non basis pada struktur perekonomian pada suatu wilayah pada dasarnya 
dapat diindentifikasi dengan menggunakan parameter Locatian Quotient (LQ) (Tan : 2010). Peningkatan kegiatan ekonomi di berbagai sektor akan memberikan dampak baik langsung maupun tidak langsung terhadap penciptaan lapangan kerja. Tanggung jawab ideal dari dunia kerja adalah bagaimana dapat menyerap sebesar-besarnya tambahan angkatan kerja yang terjadi setiap tahun, dengan tetap memperhatikan peningkatan produktivitas pekerja secara keseluruhan. Sebab dengan meningkatnya produktivitas, diharapkan upah juga meningkat sekaligus kesejahteraan pekerja dapat diperbaiki. Perubahan struktural tersebut juga memberikan dampak tidak langsung terhadap perubahan struktur ketenagakerjaannya.

Struktur perekonomian suatu daerah sangat ditentukan oleh kontribusi masing-masing sektor ekonomi dalam memproduksi barang dan jasa terhadap total PDRB. Sektor dengan kontribusi terbesar merupakan penyangga utama perekonomian regional dan berpengaruh terhadap pola sosial ekonomi masyarakat.

Sejak berdiri pada tahun 1999 Kabupaten Tebo merupakan wilayah agraris dimana lebih dari 50 persen pembentukan PDRB berasal dari sektor pertanian, peternakan, kehutanan, dan perikanan.

Dari data PDRB per sektor seperti terlihat pada tabel 1.2. bahwa dalam pembentukan struktur perekonomian terdapat sektor-sektor yang memiliki kontribusi yang cukup besar yang dijadikan sektor unggulan dan berfungsi sebagai penggerak sektor secara keseluruhan dan mendorong pertumbuhan sektor lainnya.

Tabel 2. Perkembangan PDRB Menurut Lapangan Usaha Atas Dasar Harga Konstan 2000 di Kabupaten Tebo Tahun 2005 dan 2009 (dalam jutaan rupiah)

\begin{tabular}{|r|l|r|r|r|r|}
\hline NO & \multicolumn{1}{|c|}{ SEKTOR } & \multicolumn{1}{c|}{$\begin{array}{c}\text { PDRB } \\
\mathbf{2 0 0 5}\end{array}$} & \multicolumn{1}{c|}{$\begin{array}{c}\text { Proporsi } \\
\mathbf{( \% )}\end{array}$} & \multicolumn{1}{c|}{$\begin{array}{c}\text { PDRB } \\
\mathbf{2 0 0 9}\end{array}$} & $\begin{array}{c}\text { Proporsi } \\
\mathbf{( \% )}\end{array}$ \\
\hline 1 & Pertanian & 352.220 & 53,09 & 423.710 & 49,54 \\
\hline 2 & Pertambangan \& Penggalian & 7.336 & 1,11 & 53.911 & 6,30 \\
\hline 3 & Industri Pengolahan & 19.096 & 2,88 & 23.896 & 2,79 \\
\hline 4 & Listrik,Gas dan Air Bersih & 1.533 & 0,23 & 1.892 & 0,22 \\
\hline 5 & Bangunan & 34.560 & 5,21 & 44.572 & 5,21 \\
\hline 6 & Perdagangan,Hotel,dan Restoran & 116.979 & 17,63 & 144.832 & 16,93 \\
\hline 7 & Pengangkutan \& Komunikasi & 44.253 & 6,67 & 55.360 & 6,47 \\
\hline 8 & Keuangan,Persewaan,\&Js,Perusahaan & 20.836 & 3,14 & 27.418 & 3,21 \\
\hline 9 & Jasa-jasa & 66.657 & 10,05 & 79.673 & 9,32 \\
\hline & \multicolumn{1}{|c|}{ TOTAL } & & $\mathbf{8 6 3 . 4 7 0}$ & & \\
\hline
\end{tabular}

Sumber : BPS Kabupaten Tebo (data diolah) 
Perekonomian Kabupaten Tebo saat ini masih didominasi oleh sektor pertanian dengan kontribusi terhadap Total PDRB sebesar 53,09 \% pada tahun 2005 dan mengalami penurunan proporsi pada tahun 2009 menjadi 49,54 \%. Sektor beserta subsektornya merupakan sektor primer yang akan memicu pola pertumbuhan sektor-sektor lainnya, sektor sekunder dan sektor tersier sehingga pertumbuhan setiap sektor akan bergerak secara bersama-sama dan menentukan kemampuan sektor tersebut untuk memacu pertumbuhan masing-masing lebih cepat.

Adanya sektor-sektor yang memiliki kontribusi besar seperti sektor Perdagangan,hotel dan restoran dengan proporsi sebesar 17,63 \% pada tahun 2005 dan sedikit mengalami penurunan menjadi 16,93\% pada tahun 2009 dan sektor jasa-jasa dengan proporsi sebesar $10,05 \%$ dan pada tahun 2005 terjadi penurunan sebesar 9,32\% dapat dijadikan sektor unggulan yang berfungsi sebagai motor penggerak sektor-sektor perekonomian secara menyeluruh dan mendorong pertumbuhan sektor lain dengan keterkaitan antar sektor. Untuk mempercepat akselerasi pertumbuhan sektor unggulan maka perlu didukung dengan anggaran pengeluaran yang mendukung pertumbuhan sektor unggulan tersebut.

Tabel tersebut diatas menggambarkan perbedaan yang sangat mencolok antara sektor pertanian dan sektor lainnya menunjukkan belum adanya keterkaitan yang erat antara masingmasing sektor dimana sektor industri pengolahan masih terbatas pada pengolahan komoditas tertentu (hasil perkebunan) dan belum menyentuh komoditas lainnya, terutama hasil pertambangan (minyak bumi dan batubara), yang menyebabkan nilai tambah hanya sebatas penjualan bahan baku (mentah) dan bukan produk olahan. Hal ini dapat menyebabkan terjadinya ketimpangan antar sektor yang cukup besar di Kabupaten Tebo dimana sektor pertanian masih menjadi kontributor utama atas struktur perekonomian regional dalam pembentukan PDRB yaitu hampir dari separuh total PDRB di sumbangkan dari sektor pertanian dan diikuti oleh sektor Perdagangan, Hotel dan Restoran yang menyumbangkan lebih dari $15 \%$ serta sektor lainnya menyumbangkan tidak lebih dari $10 \%$ dari total PDRB Kabupaten Tebo.

Lambatnya pergerakan sektor-sektor lain dalam perekonomian di Kabupaten Tebo akan berdampak dengan ketimpangan pendapatan masyarakat. Dari fenomena tersebut peran Pemerintah Daerah seharusnya dapat optimal dengan membuat kebijakan-kebijakan perencanaan pembangunan di daerahnya agar dapat menggerakkan sektor-sektor lain untuk tumbuh dan akhirnya memperkecil ketimpangan antar sektor dalam perekonomian. 
Bertolak dari data diatas terlihat bahwa dalam pembentukan struktur perekonomian, ada sektor-sektor yang memiliki kontribusi besar yang dijadikan serktor unggulan yang berfungsi sebagai sektor penggerak sektor secara keseluruhan dan mendorong sektor lain dengan keterkaitan antar sektor (Backward and forward linkage). Hal ini berarti akan terjadi pergeseran dan perubahan-perubahan perekonomian Kabupaten Tebo secara struktural akibat pertumbuhan di berbagai sektor ekonomi dan juga nantinya akan mengurangi tingkat ketimpangan antar sektor.

Dengan uraian diatas, maka penulis tertarik melakukan suatu kajian yang lebih mendalam yang dituangkan dalam bentuk penelitian mengenai “Analisis Struktur Ekonomi dan Ketimpangan Antar Sektor di Kabupaten Tebo Periode 2001 - 2010”.

\section{Rumusan Masalah}

Berdasarkan belakang penelitian yang ada maka dapat dirumuskan permasalahan sebagai berikut :

1. Bagaimana struktur dan pola pertumbuhan sektor ekonomi di Kabupaten Tebo periode $2001-2010 ?$

2. Sektor manakah yang menjadi sektor unggulan di kabupaten Tebo periode 2001 - 2010 ?

3. Bagaimana tingkat ketimpangan antar sektor di Kabupaten Tebo periode 2001 - 2010 ?

\section{Landasan Teori}

\section{Pembangunan Ekonomi}

Suatu perekonomian dikatakan mengalami pertumbuhan atau berkembang apabila tingkat kegiatan ekonomi lebih tinggi dari pada apa yang dicapai pada masa sebelumnya. Artinya perkembangan baru tercipta apabila jumlah barang dan jasa yang dihasilkan dalam perekonomian tersebut menjadi bertambah besar pada tahun-tahun berikutnya (Sukirno, 1985).

Arsyad (1999) menyebutkan bahwa berdasarkan teori kutub pertumbuhan yang dipopulerkan oleh ekonom Perancis Perroux menjadi dasar strategi kebijakan industri daerah, Perroux berpendapat bahwa pertumbuhan tidak muncul di berbagai daerah pada waktu yang sama. Pertumbuhan hanya terjadi di beberapa tempat yang merupakan pusat (kutub) pertumbuhan dengan intensitas yang berbeda, inti teori dari Perroux adalah sebagai berikut.

1. Dalam proses perubahan akan timbul industri unggulan yang merupakan industri penggerak utama dalam pembangunan suatu daerah. Karena keterkaitan antara industri 
sangat erat, maka perkembangan industri unggulan akan mempengaruhi perkembangan industri lain yang berhubungan erat dengan industri unggulan tersebut.

2. Pemusatan industri pada suatu daerah akan mempercepat pertumbuhan perekonomian, karena pemusatan industri akan menciptakan pola konsumsi yang berbeda antardaerah sehingga perkembangan industri di daerah tersebut akan mempengaruhi perkembangan daerah-daerah lainnya.

3. Perekonomian merupakan gabungan dari sistem industri yang relatif aktif (industri unggulan) dengan industri-industri yang relatif pasif yaitu industri yang tergantung dengan industri unggulan/pusat pertumbuhan. Daerah yang relatif maju/aktif akan mempengaruhi daerah-daerah yang relatif pasif

Menurut Todaro (2000),pembangunan ekonomi (Development) secara tradisional diartikan sebagai kapasitas dari sebuah perekonomian nasional yang kondisi-kondisi ekonomi awalnya kurang lebih bersifat statis dalam waktu cukup lama untuk menciptakan dan mempertahankan Gross National Bruto (GDP), sedang pandangan baru tolok ukur pembangunan ekonomi tidak hanya menciptakan tingkat pertumbuhan ekonomi yang setinggi-tingginya melainkan pengurangan kemiskinan, penanggulangan ketimpangan pendapatan, dan penyediaan lapangan pekerjaan dalam konteks perekonomian lebih luas.

\section{Pertumbuhan Ekonomi}

Menurut pandangan ekonom klasik, Adam Smith, David Ricardo, Thomas Robert Malthus dan John Straurt Mill, maupun ekonom neo klasik, Robert Solow dan Trevor Swan, mengemukakan bahwa pada dasarnya ada empat faktor yang mempengaruhi pertumbuhan ekonomi yaitu (1) jumlah penduduk, (2) jumlah stok barang modal, (3) luas tanah dan kekayaan alam, dan (4) tingkat teknologi yang digunakan (Sukirno, 1985). Suatu perekonomian dikatakan mengalami pertumbuhan atau berkembang apabila tingkat kegiatan ekonomi lebih tinggi dari pada apa yang dicapai pada masa sebelumnya. Artinya perkembangan baru tercipta apabila jumlah barang dan jasa yang dihasilkan dalam perekonomian tersebut menjadi bertambah besar pada tahun-tahun berikutnya.

Menurut Boediono (1985) pertumbuhan ekonomi adalah proses kenaikan output per kapita dalam jangka panjang. Penekanan pada proses karena proses mengandung unsur dinamis. Para teoritisi ilmu ekonomi pembangunan masa kini, masih terus menyempurnakan makna, hakikat dan konsep pertumbuhan ekonomi, Para teoritisi tersebut menyatakan bahwa pertumbuhan ekonomi tidak hanya diukur dengan pertambahan PDB dan PDRB saja, tetapi 
juga diberi bobot yang bersifat immaterial seperti kenikmatan, kepuasan dan kebahagiaan dengan rasa aman dan tentram yang dirasakan masyarakat luas (Arsyad, 1999).

\section{Teori Basis Ekonomi}

Teori basis ekonomi adalah sektor-sektor ekonomi yang mempunyai nilai location quotient lebih dari 1, sektor ini disebut juga sektor basis. sedangkan menurut analisis input output, terdapat empat metode yang digunakan dalam mengidentifikasi sektor potensial atau sektor kunci(Sritua Arif,1996), yaitu :

1. Suatu sektor dianggap sebagai sektor kunci apabila mempunyai keterkaitan kebelakang (backward linkage) dan keterkaitan kedepan (forewad linkage) yang relatif tinggi ( $>1$ ).

2. Suatu sektor dianggap sebagai sektor kunci apabila menghasilkan output bruto yang relatif tinggi, sehingga mampu mempertahankan permintaan terakhir (finan demand) yang ralatif tinggi juga.

3. Suatu sektor dianggap sebagai sektor kunci apabila mampu menghasilkan penerimaan devisa bersih yang relatif tinggi.

4. Suatu sektor dianggap sebagai sektor kunci apabila mampu menciptakan lapangan kerja yang relatif tinggi.

\section{Transformasi Struktural}

Pembangunan yang selama ini telah menghasilkan pertumbuhan yang cukup tinggi, ternyata hasil pembangunan tersebut belum sepenuhnya dinikmati secara merata oleh seluruh lapisan atau berbagai golongan penduduk seluruh daerah atau dengan kata lain belum sepenuhnya dapat mengatasi permasalahan ketimpangan. Kuznets dan Chenerry melalui penelitiannya, menyimpulkan bahwa sebagai proses alokasi pembangunan ekonomi dapat dianggap sebagai suatu proses pertumbuhan ekonomi atau proses peningkatan pendapatan nasional per kapita yang disertai dengan, antara lain transformasi ekonomi (economic transformations) dari suatu perekonomian yang dominan sektor pertanian menjadi dominan sektor industri pengolahan (manufacture) dan sektor jasa (service) (Sukimo, 1999).

Transformasi ekonomi tidak saja menyangkut perubahan pada struktur produksi tetapi juga menyangkut perubahan struktur tenaga kerja, perdagangan dan struktur industri. Pengertian wilayah daerah lebih terbuka dibandingkan dengan wilayah nasional, bila dilihat dari pergerakan sumber daya antar daerah lebih bebas dibandingkan dengan pergerakan 
sumber daya antar negara. Pergerakan sumber daya yang lebih bebas dimaksud, karena halangan berupa tarif, kuota, lisensi ekspor hampir dikatakan tanpa hambatan dalam pergerakannya antar daerah. Proses akumulasi sumber-sumber, berupa akumulasi modal, keterampilan tenaga kerja dan sumber daya alam yang dimiliki oleh suatu daerah merupakan pemicu dalam laju pertumbuhan ekonomi wilayah yang bersangkutan. Adanya heterogenitas dan beragam karakteristik suatu wilayah menyebabkan terjadinya ketimpangan antar daerah dan antar sektor ekonomi suatu daerah.

\section{TIPOLOGI KLASSEN}

Tipologi klassen merupakan tehnik pengelompokkan daerah menurut struktur pertumbuhan dan tingkat pembangunan ini antara lain dapat dilakukan dengan menggunakan matrik tipologi klassen, dimana pengelompokkan daerah disajikan dalam bentuk diagram empat kuadran, dengan menggunakan 2 (dua) indikator utama yaitu sumbu vertikal menggambarkan laju pertumbuhan ekonomi dan sumbu horizontal menggambarkan tingkat pendapatan PDRB perkapita, pada tengah masing-masing sumbu (vertikal dan horisontal)digambarkan garis tegak lurus pada masing-masing sumbu. Garis-garis ini menggambarkan rata-rata tingkat pertumbuhan ekonomi (tegak lurus dengan garis vertikal) dan rata-rata PDRB perkapita (tegak lurus dengan garis horisontal).Garis-garis tersebut membagi bidang grafik menjadi 4 (empat) kuadran.

\section{Metode Penelitian}

\section{Metode Analisis}

Alat analisis yang digunakan adalah alat analisis deskriptif yang menggambarkan fenomena-fenomena trend perkembangan sektoral terhadap PDRB kabupaten Tebo dan Analisa kuantitatif didasarkan pada analisa variabel-variabel yang dapat dijelaskan secara kuantitas (dapat diukur) dengan rumus-rumus atau alat analisa pasti.

\section{Jenis dan Sumber Data}

Jenis data yang digunakan dalam penelitian ini adalah data sekunder, yaitu data yang diambil dari pihak lain atau merupakan data yang sudah diolah pihak kedua.yang bersumber dari Badan Pusat Statistik Kabupaten Tebo. 
Analisis yang digunakan adalah analisis kuantitatif didasarkan pada analisa variabelvariabel yang dapat dijelaskan secara kuantitas (dapat diukur) dengan rumus-rumus atau alat analisa pasti.

Untuk menjawab masalah pertama bagaimana struktur dan pola pertumbuhan sektor ekonomi di Kabupaten Tebo digunakan analisis deskriktif dan analisis kuantitatif, analisis deskriftif digunakan untuk mengetahui dan menganalisis struktur pertumbuhan ekonomi di kabupaten Tebo, dimana pengelompokkan 9 (sembilan) sektor di klasifikasikan menjadi 3 (tiga) kelompok besar yaitu sektor primer, skunder dan tersier. Dengan menggunakan alat analisis tipologi klassen dengan Formulasi alat analisis sebagai berikut.

\section{Klasifikasi Pertumbuhan Ekonomi menurut Tipologi Klassen}

\begin{tabular}{|c|c|c|}
\hline Kontribusi persektor & yi $<\mathrm{y}$ & yi $>\mathrm{y}$ \\
\hline $\mathrm{ri}>\mathrm{r}$ & $\begin{array}{c}\text { Kontribusi rendah dan } \\
\text { pertumbuhan tinggi }\end{array}$ & $\begin{array}{c}\text { Kontribusi tinggi dan } \\
\text { pertumbuhan tinggi }\end{array}$ \\
\hline $\mathrm{ri}<\mathrm{r}$ & $\begin{array}{c}\text { Kontribusi rendah dan } \\
\text { pertumbuhan rendah }\end{array}$ & $\begin{array}{c}\text { Kontribusi Tinggi dan } \\
\text { pertumbuhan rendah }\end{array}$ \\
\hline
\end{tabular}

Sumber : Sjafrizal (1997)

Keterangan : $\quad \mathrm{ri}=$ laju pertumbuhan persektor PDRB Kabupaten Tebo

$\mathrm{r}=$ laju pertumbuhan persektor PDRB Propinsi Jambi

$\mathrm{y}_{1}=$ Kontribusi persektor dalam PDRB Kabupaten Tebo

$\mathrm{y}=$ Kontribusi persektor dalam PDRB Propinsi Jambi

Untuk masalah kedua yaitu mengetahui dan menganalisis sektor mana yang menjadi sektor unggulan di kabupaten Tebo digunakan Metode analisis Location Quotient atau disingkat LQ. Dengan formula yang dikemukakan oleh Blakely $(2002,123)$ sebagai berikut :

$$
\mathrm{LQ}=\frac{E_{i}^{R} / E^{R}}{E_{i}^{N} / E^{N}}
$$

Keterangan :

LQ : Location Quetient

$E_{i}^{R} \quad:$ PDRB di sektor i di Kabupaten Tebo

$E^{R} \quad$ : Total PDRB seluruh sektor i di Kabupaten Tebo

$E_{i}^{N} \quad:$ PDRB sektor i di Provinsi Jambi

$E^{N} \quad:$ PDRB seluruh sektor i di Provinsi Jambi

Kriteria pengukuran dari nilai LQ yang dihasilkan mengacu pada kriteria yang dikemukakan Bendavid-Val (1991) sebagai berikut : 
1. LQ>1, berarti sektor i memiliki tingkat spesialisasi yang berlebihan/ berpotensi ekspor inter daerah (sektor utama).

2. LQ $<1$, berarti sektor i kurang memiliki tingkat spesialisasi berpotensi impor inter daerah (sektor non utama).

3. $\mathrm{LQ}=1$, berarti sektor i memiliki tingkat spesialisasi/ yang cukup seimbang (kondisi seimbang).

Dengan ketentuan bila LQ>1 maka subsektor tersebut merupakan subsektor unggulan di daerah dan potensial untuk dikembangkan sebagai penggerak perekonomian daerah. Apabila LQ $<1$ maka subsektor tersebut bukan merupakan subsektor unggulan dan kurang potensial untuk dikembangkan sebagai penggerak perekonomian daerah.

Untuk menjawab masalah ketiga yaitu mengetahui tingkat ketimpangan antar sektor di kabupaten Tebo digunakan alat analisis Balance Growth Index dengan formula sebagai berikut:

$B \underset{I-n}{j-s}=\frac{1}{G_{I-n}^{j-s}} \sqrt{\frac{1}{k} \sum_{1=1}^{k} W_{i, 1}^{j-s}\left(g_{I-n}^{j-s}-G_{I-n}^{j-s}\right)}$

dimana :

$B_{1-n}^{j-s}=$ Indeks pertumbuhan yang seimbang untuk daerah Kabupaten Tebo selama kurun waktu $n$ tahun

$G_{1-n}^{j-s}=$ Laju pertumbuhan PDRB rata-rata tahun ke 1 hingga tahun ke $\mathrm{n}$ pada Kabupaten Tebo

$\mathrm{i}=$ Banyaknya sektor ekonomi yang terdapat di Kabupaten Tebo

$W_{i-1}^{j-s}=$ Sumbangan sektor i terhadap PDRB dalam bentuk persentase pada tahun ke 1 di Kabupaten Tebo

$g_{i, 1-n}^{j-s}=$ Laju pertumbuhan rata-rata sektor i di Kabupaten Tebo

Indeks yang semakin rendah (mendekati nol) menunjukan makin berimbang pertumbuhan antar sektor dan akan menghasilkan rata-rata pertumbuhan ekonomi daerah yang semakin tinggi dan demikian pula sebaliknya.

\section{Pembahasan}

Struktur Pertumbuhan Sektor Ekonomi di Kabupaten Tebo Tahun 2001-2010

Berdasarkan hasil analisis struktur pertumbuhan ekonomi di Kabupaten Tebo dalam pembentukan PDRB selama tahun 2001-2010 masih didominasi oleh sektor Primer (Pertanian dan Pertambangan, Penggalian) dimana rata-rata kontribusi sektor primer yaitu sebesar 54,87 
persen. Sedangkan rata-rata kontribusi sektor sekunder (sektor industri pengelohan, sektor listrik, gas dan air minum serta sektor pembangunan) adalah sebesar 8,22 persen dan rata-rata kontribusi sektor tersier (perdagangan, hotel dan restoran, pengangkutan dan komunikasi, bank dan lembaga keuangan lainnya serta sektor jasa-jasa) adalah sebesar 26,92 persen.

Perbedaan yang sangat mencolok antara sektor primer dan sektor sekunder menunjukkan belum adanya keterkaitan yang erat antara kedua sektor, dimana sektor industri pengolahan masih terbatas pada pengolahan komoditas tertentu (hasil perkebunan) dan belum menyentuh komoditas lainnya, terutama hasil pertambangan (minyak bumi dan batubara), yang menyebabkan pembentukan nilai tambah hanya sebatas penjualan bahan baku (mentah) dan bukan produk olahan.

\section{Pola Pertumbuhan Sektor Ekonomi di Kabupaten Tebo Tahun 2001 - 2010}

Sebagai implikasi dari perbedaan struktur dan potensi ekonomi wilayah, pertumbuhan ekonomi masing-masing daerah cenderung sangat bervariasi satu sama lainnya. Ada daerah yang mengalami pertumbuhan ekonomi yang sangat cepat, tetapi ada pula yang relatif lambat dan bahkan ada pula yang mengalami stagnasi sama sekali. Kondisi tersebut tentunya akan mempengaruhi tingkat kemakmuran masyarakat pada masing-masing daerah bersangkutan, ada yang telah berkembang menjadi daerah maju, daerah sedang berkembang dan ada pula masih merupakan daerah yang relatif masih terbelakang

Kuadrant Pola Pertumbuhan Ekonomi berdasarkan Analisis Tipologi Klassen di Kabupaten

\begin{tabular}{|c|c|c|}
\hline Kontribusi y & yi $<$ y & $y i>y$ \\
\hline $\mathrm{ri}>\mathrm{r}$ & $\begin{array}{l}\text { KUADRAN I } \\
\text { - Pertambangan } \\
\text { - Pengangkutan }\end{array}$ & KUADRAN II \\
\hline $\mathrm{ri}<\mathrm{r}$ & $\begin{array}{l}\quad \text { KUADRAN IV } \\
\text { - Industri Pengolahan } \\
\text { - Listrik } \\
\text { - Keuangan }\end{array}$ & $\begin{array}{l}\quad \text { KUADRAN III } \\
\text { - Pertanian } \\
\text { - Bangunan } \\
\text { - Perdagangan } \\
\text { - Jasa-jasa }\end{array}$ \\
\hline
\end{tabular}

Berdasarkan hasil pengelompokkan dengan Tipologi Klassen yang menggunakan ratarata pertumbuhan persektor PDRB dan Kontribusi persektor PDRB di Kabupaten Tebo selama tahun 2001-2010, Pada klasifikasi sektor yang berkembang cepat kuadran I dimana Kontribusi lebih rendah dibandingkan propinsi akan tetapi pertumbuhannya lebih tinggi dibandingkan propinsi terdapat dua sektor yaitu Sektor Pertambangan dan penggalian nilai 
kontribusi dan pertumbuhan PDRB yaitu sebesar 3,53<12,78 dan 51,18 $>3,57$, Sektor Pengangkutan dan Komunikasi 6,47 < 7,98 dan 5,63 > 5,01.

Pada Klasifikasi Sektor maju dan tumbuh cepat Kuadran II dimana rata-rata pertumbuhan persektor PDRB dan kontribusi persektor PDRB lebih tinggi dari pada propinsi Jambi, selama periode penelitian di Kabupaten Tebo tidak ada sektor ekonomi yang termasuk dalam Kuadran II, hal ini disebabkan karena Kabupaten Tebo merupakan Kabupaten pemekaran dimana sektor-sektor perekonomian masih memungkinkan untuk di kembangkan, dan kekayaan berupa sumber daya alam belum maksimal dimanfaatkan.

Pada sektor maju tapi tertekan kuadran III terdapat empat sektor perekonomian dimana dalam periode penelitian pertumbuhannya relatif lebih kecil dibandingkan propinsi tetapi kontribusinya lebih tinggi daripada propinsi, yaitu sektor pertanian dengan nilai kontribusi dan pertumbuhan PDRB yaitu sebesar 51,34 > 31,00 dan 4,31<5,15, Sektor Bangunan 5,05 > 3,91 dan 5,57 < 15,37 Sektor Perdagangan, hotel dan restoran, pengangkutan dan komunikasi, bank dan lembaga keuangan lainnya 17,57>16,93 dan 4,01< 6,32 serta Sektor Jasa-jasa 9,72>9,18 dan 3,81<4,05.

Sedangkan pada sektor yang relatif tertinggal kuadran IV dimana pertumbuhannya maupun kontribusinya lebih rendah dibandingkan propinsi terdapat tiga sektor yaitu sektor industri pengolohan, Sektor listrik, gas dan air bersih serta Sektor Keuangan lainnya.

\section{Sektor Unggulan di Kabupaten Tebo Tahun 2001 - 2010}

Hasil perhitungan Location Quetient di Kabupaten Tebo selama tahun 2001 - 2010 menunjukkan bahwa, di Kabupaten Tebo memiliki 3 sektor unggulan "locational" yaitu sektor pertanian, sektor bangunan dan sektor jasa-jasa. Sektor dengan skor tertinggi selama 5 tahun terakhir adalah sektor pertanian dengan LQ sebesar 1,64. Sektor pertanian merupakan sektor penyerap tenaga kerja tertinggi dan menjadi kontributor utama atas total PDRB Kabupaten Tebo.

Sektor pertanian menjadi sektor unggulan dengan skor LQ paling tinggi sebab selain telah terbangun sejak lama, sektor pertanian mengandalkan komoditas yang memiliki nilai jual dan permintaan yang tinggi (Karet dan Kelapa Sawit). Sektor bangunan dan sektor jasajasa (khususnya jasa pemerintah) menjadi sektor unggulan sebab pembangunan infrastruktur di Kabupaten Tebo sebagai kabupaten pemekaran masih berjalan, seperti pembangunan gedung-gedung perkantoran, perluasan, pelebaran jalan, pembangunan jembatan dan lain 
sebagainya. Pemerintah Kabupaten Tebo terus berupaya mengejar pembangunan fasilitas umum untuk memudahkan masyarakat menikmati akses transportasi dan melancarkan roda perekonomian.

Nilai masing-masing sektor secara berurutan adalah : sektor pertanian $(1,64)$ sektor jasa-jasa $(1,08)$ sektor bangunan $(1,06)$ sektor perdagangan, hotel dan restoran $(0,98)$ sektor pengangkutan dan komunikasi $(0,85)$ sektor keuangan,persewaan dan jasa perusahaan $(0,56)$ sektor pertambangan dan penggalian $(0,50)$ sektor listrik,gas dan air bersih $(0,26)$ dan yang terakhir dengan skor yang paling kecil adalah sektor industri pengolahan $(0,22)$.

Skor Location Quetion PDRB Per Sektor Provinsi Jambi Menurut Lapangan Usaha Atas Dasar Harga Konstan Tahun 2001 - 2010

\begin{tabular}{|c|c|c|c|c|c|c|c|c|c|c|}
\hline \multirow{2}{*}{ SEKTOR } & \multicolumn{10}{|c|}{ Skor Location Quotient Sektoral Kabupaten Tebo } \\
\hline & 2001 & 2002 & 2003 & 2004 & 2005 & 2006 & 2007 & 2008 & 2009 & 2010 \\
\hline 1.Pertanian & 1,68 & 1,67 & 1,70 & 1,74 & 1,74 & 1,58 & 1,62 & 1,59 & 1,60 & 1,64 \\
\hline 2.Pertambangan \& Penggalian & 0,07 & 0,07 & 0,07 & 0,08 & 0,09 & 0,49 & 0,46 & 0,57 & 0,54 & 0,50 \\
\hline 3.Industri Pengolahan & 0,22 & 0,22 & 0,22 & 0,22 & 0,22 & 0,22 & 0,23 & 0,23 & 0,22 & 0,22 \\
\hline 4.Listrik, Gas dan Air Bersih & 0,46 & 0,45 & 0,41 & 0,30 & 0,30 & 0,28 & 0,28 & 0,28 & 0,28 & 0,26 \\
\hline 5.Bangunan & 2,36 & 1,88 & 1,56 & 1,37 & 1,22 & 1,17 & 1,09 & 1,07 & 1,08 & 1,06 \\
\hline 6.Perdagangan,Hotel,dan Restoran & 1,15 & 1,14 & 1,13 & 1,06 & 1,03 & 0,96 & 0,96 & 0,99 & 0,99 & 0,98 \\
\hline 7.Pengangkutan \& Komunikasi & 0,76 & 0,80 & 0,83 & 0,80 & 0,82 & 0,82 & 0,79 & 0,83 & 0,82 & 0,85 \\
\hline 8.Keuangan,Persewaan, \&Js,Perusahaan & 0,98 & 1,01 & 0,94 & 0,82 & 0,81 & 0,79 & 0,72 & 0,64 & 0,58 & 0,56 \\
\hline 9.Jasa-jasa & 1,10 & 1,05 & 1,05 & 1,07 & 1,08 & 1,03 & 1,03 & 1,04 & 1,06 & 1,08 \\
\hline TOTAL & 1,00 & 1,00 & 1,00 & 1,00 & 1,00 & 1,00 & 1,00 & 1,00 & 1,00 & 1,00 \\
\hline
\end{tabular}

Tingkat Ketimpangan Antar Sektor di Kabupaten Tebo Tahun 200 -2010

Tingkat ketimpangan antar sektor dalam penelitian ini menggunakan alat analisis Balance Growth Index dimana perbedaan pertumbuhan antar sektor terhadap pertumbuhan ekonomi rata-rata suatu daerah dalam periode tertentu, sehingga pada tahap selanjutnya akan diperoleh gambaran keseimbangan pertumbuhan pada suatu daerah.

Tabel Indeks Keseimbangan Antar Sektor Ekonomi di Kabupaten Tebo Tahun 2001 - 2010

\begin{tabular}{|c|c|c|c|c|c|c|c|}
\hline \multirow{2}{*}{ SEKTOR EKONOMI } & W & g & \multirow{2}{*}{ Tahun } & G & $=(\mathrm{g}-\mathrm{G})$ & $(g-G) 2$ & $(1 \times 4)$ \\
\hline & 1 & 2 & & 3 & 4 & $(g-G) 2$ & 5 \\
\hline 1.Pertanian & 52,62 & 0,48 & 2001 & 0,00 & 0,48 & 0,23 & 12,06 \\
\hline 2.Pertambangan \& Penggalian & 0,99 & 5,69 & 2002 & 2,18 & 3,51 & 12,31 & 12,19 \\
\hline 3.Industri Pengolahan & 3,11 & 0,39 & 2003 & 1,49 & $-1,10$ & 1,20 & 3,74 \\
\hline 4.Listrik,Gas dan Air Bersih & 0,25 & 0,42 & 2004 & 8,40 & $-7,98$ & 63,72 & 15,73 \\
\hline 5.Bangunan & 4,82 & 0,62 & 2005 & 4,77 & $-4,15$ & 17,25 & 83,13 \\
\hline 6.Perdagangan,Hotel,dan Restoran & 18,73 & 0,45 & 2006 & 9,65 & $-9,21$ & 84,80 & $1.588,46$ \\
\hline 7.Pengngkutan \& Komunikasi & 6,05 & 0,63 & 2007 & 5,46 & $-4,84$ & 23,42 & 141,69 \\
\hline 8.Keuangan,Persewaan,\&Js,Perusahaan & 3,17 & 0,57 & 2008 & 6,07 & $-5,50$ & 30,22 & 95,89 \\
\hline 9.Jasa-jasa & 10,26 & 0,42 & 2009 & 5,09 & $-4,67$ & 21,77 & 223,21 \\
\hline TOTAL & & & 2010 & 6,06 & $-6,06$ & 36,71 & 0,00 \\
\hline & 100,00 & 9,66 & & 49,18 & & & $2.176,11$ \\
\hline
\end{tabular}




$$
\begin{aligned}
B \begin{array}{l}
j-s \\
I-n
\end{array}=\frac{1}{4,1} \sqrt{\frac{1}{1} \times 2.176,11} \\
=0,0203 \sqrt{ } 21 \overline{17.610} \\
=0,299
\end{aligned}
$$

Pada tabel diatas memperlihatkan bahwa dari hasil perhitungan indeks keseimbangan pertumbuhan pertumbuhan antar sektor ekonomi di Kabupaten Tebo di peroleh hasil sebesar 0,299 hal ini menggambarkan bahwa pertumbuhan ekonomi antar sektor di kabupaten Tebo tidak seimbang atau terjadi ketimpangan, dimana kriteria yang di gunakan dalam indeks keseimbangan adalah jika nilai indeks keseimbangan mendekati nol maka indeks tersebut dinyatakan semakin seimbang sedangkan bila nilai indeks yang ada menjauhi nol maka nilai indeks tersebut semakin tidak seimbang.

Besarnya nilai indek keseimbangan sektor ekonomi sebesar 0,299 ini mengartikan bahwa peningkatan atau pertumbuhan yang terjadi pada masing-masing sektor ekonomi tidak mampu meningkatkan dan mengembangkan sektor yang lainnya, dimana sektor pertanian, pertambangan dan sektor penggalian cukup pesat peningkatannya dibandingkan sektor ekonomi lainnya hal ini menggambarkan adanya ketimpangan antar sektor di Kabupaten Tebo.

\section{Kesimpulan dan Saran}

\section{Kesimpulan}

Berdasarkan hasil analisis yang telah dilakukan maka diperoleh kesimpulan sebagai berikut:

1. Struktur pertumbuhan ekonomi di Kabupaten Tebo selama tahun $2001-2010$ masih di domiasi oleh sektor primer dimana rata-rata kontribusi sebesar 54,87 persen, sektor sekunder adalah sebesar 8,22 persen serta sektor tersier sebesar 26,92 persen.

Berdasarkan analisa tipologi klassen pola pertumbuhan ekonomi di Kabupaten Tebo dimana Sektor Primer hanya Sektor Pertanian berada pada Kuadran III sedangkan sektor Pertambangan dan penggalian berada pada Kuadran I, Sektor Skunder yang berada pada kuadran III adalah Sektor Bangunan sedangkan Sektor Industri pengelohan, sektor listrik, gas dan air minum berada pada kuadran IV dan Sektor Tersier yang berada pada Kuadran I yaitu Sektor Pengangkutan dan Telekomunikasi sedangkan Perdagangan, perdagangan, hotel dan restoran dan Sektor Jasa-jasa berada pada Kuadran III, Sektor yang berada pada Kuadran IV adalah Sektor Keuangan, bank 
dan lembaga keuangan lainnya. Keadaan tersebut menunjukkan kecilnya keterkaitan antar sektor ekonomi di Kabupaten Tebo karena kebijakan pembangunan di Kabupaten Tebo belum terencana dengan baik.

2. Sektor ekonomi yang relatif memiliki keunggulan "locational" karena memiliki nilai LQ > 1 di Kabupaten Tebo selama tahun 2001 - 2010 yaitu pada sektor pertanian, sektor bangunan dan sektor jasa-jasa. Sektor dengan skor tertinggi selama 5 tahun terakhir adalah sektor pertanian dengan LQ sebesar $(1,64)$ sektor jasa-jasa $(1,08)$ serta sektor bangunan $(1,06)$

3. Berdasarkan perhitungan indeks keseimbangan pertumbuhan di Kabupaten Tebo tahun 2001 - 2010 diperoleh hasil rata-rata indeks keseimbangan sebesar 0,299, hal ini menggambarkan bahwa adanya ketimpangan antar sektor ekonomi di Kabupaten Tebo.

\section{Daftar Pustaka}

Amir, Amri 2007, Pembangunan dan Kualitas Pertumbuhan Ekonomi Dalam Era Globalisasi, Biografika, Bogor.

Arsyad, Lincoln 1999, Pengantar Perencanaan dan Pembangunan Ekonomi Daerah, Fakultas Ekonomi Yogyakarta.

Arsyad, Lincoln 2004, Ekonomi Pembangunan Edisi ke-4, STIE YKPN,Yogyakarta

Aswandi, H., \& Kuncoro, M. (2002), Evaluasi Penetapan Kawasan Andalan : Stusi Empiris di Kalimantan Selatan 1993-1999. Jurnal Ekonomi dan Bisnis Indonesia.

Badan Pusat Statistik Kabupaten Tebo, Pendapatan Domestik Regional Bruto (PDRB) beberapa terbitan, BPS Kabupaten Tebo.

Badan Pusat Statistik Kabupaten Tebo, Tebo Dalam Angka beberapa terbitan, BPS Kabupaten Tebo

Barata Kusumah, Deddy 2001, Otonomi Penyelenggaraan Pemerintah Daerah, Gramedia, Jakarta.

Hafizrianda, Yundi 2011, Model-model Kuantitatif Dalam Perencanaan Pembangunan Wilayah. 
Jurnal Ekonomi Pembangunan 2002 “Kajian Negara Berkembang, Hal 33-44” Disparitas dan Pola Spesialisasi Tenaga Kerja Industri Regional 1993 - 1996 dan Prospek Ekonomi.

Kuncoro, Mudrajad 2004, Otonomi dan Pembangunan Daerah, Erlangga, Jakarta.

Mubyarto, Novi 2007, AnalisisEkonomi Basis dan potensi investasi swasta di Propinsi Jambi, Tesis S-2 Program Pascasarjana, Universitas Jambi, tidak dipublikasikan.

Setyaningrum, Sus 2001. Analisis Struktur Perekonomian Provinsi Daerah Istimewa Yogyakarta. Skripsi Tidak Dipublikasikan.

Tan, Syamsurijal, 2010, Pengembangan Pembangunan (Teori dan Implementasi), Fakultas Ekonomi Universitas Jambi.

Wijakso, Eko 2010, Analisis Pertumbuhan Ekonomi Kabupaten Bungo, Tesis S-2 Program Pascasarjana, Universitas Jambi, tidak dipublikasikan. 